\title{
ENTRE IMAGENS E PESSOAS - PERCURSOS DE FORMAÇÃO E CRIAÇÃO
}

Wenceslao Machado de Oliveira Jr ${ }^{1}$

O segundo número de 2017 da revista ETD - Educação Temática Digital publica o dossiê Cinema, Educação e seus processos de formação, organizado pelas professoras Adriana Hoffmann e Maria da Conceição Silva Soares.

Nos oito artigos presentes no dossiê os leitores entrarão em contato com diversas formas em que a educação se (con)forma em interface com o cinema, assim como com diversas formas em que o cinema se (con)forma em interface com a educação. Em ambas as direções dessa interface o que encontramos nos artigos e ensaios aqui publicados não é propriamente a colocação das pessoas e imagens em fôrmas já dadas; ao contrário, o que perpassa todos os textos são diferentes - e mesmo imprevisíveis - modos como pessoas e imagens se disformam ao mesmo tempo que se conformam mutuamente em cada uma das experiências relatadas e discutidas acerca do encontro entre cinema e educação.

Nesse sentido, podemos dizer que a palavra formação assume sentidos mais aproximados de criação; criação mútua que se dá através dos próprios encontros entre pessoas e imagens e das experiências deles desdobradas: pequenas, médias e grandes metamorfoses; sutis, notáveis e devastadores desvios; intensas, inusitadas e frágeis parcerias; aproximações, distanciamentos e descobertas de outras imagens e outras pessoas criadas no

\footnotetext{
${ }^{1}$ Professor da Faculdade de Educação - Universidade Estadual de Campinas (UNICAMP) - Campinas, SP - Brasil. Editor Científico - ETD - Educação Temática Digital. E-mail: wenceslao.oliveira@gmail.com
}

(C) ETD-Educação Temática Digital Campinas, SP v.19 $\quad$ n.2 $\quad$ p. 305-306 abr./jun. 2017 
entrelaçar dos encantamentos, desconfianças e semelhanças existentes entre os processos de formação que atravessam tanto o cinema como a educação como modos de subjetivação e modos de produção de cultura.

Em uma feliz coincidência, três dos cinco artigos de demanda contínua publicados nesse número também exploram processos de formação efetivados no encontro entre pessoas e imagens: de cinema, de videogame e de jogo online.

A fotografia de capa funciona como mais um artigo. De autoria de outro pesquisador das relações entre imagens e educação, Paulo Carrano nos brinda com uma cena onde cinema e escola se configuram mutuamente justo no instante em que misturam seus hábitos de observar coletivamente um único ponto do mundo. Em um local vazio e quase escuro, o brilho da luz projetada abre uma janela na parede. Janela aberta para a paisagem... do cinema na educação. Um cinema que se abre ainda mais para o detalhe, para o olhar meticuloso que ao mirar - e projetar - o mundo na escola (trans)forma-o em boca ávida e falante: criança que se lança em descobertas e falações. Na penumbra do local, entreve-se carteiras e caixotes, papéis colados na parede pintada com outra paisagem; intui-se ali a presença do fotógrafo e de uma plateia que agrupa inúmeras outras bocas ávidas e silenciosas em meio a muitos ouvidos e olhos atentos às próximas imagens que abrirão paisagens a um só tempo mínimas e grandiosas naquela parece.

Agradecemos às organizadoras do dossiê e aos demais autores desse número da revista por nos abrirem os olhos para estas outras paisagens que se fazem visíveis no encontro entre cinema e educação, desejando que seus textos e imagens projetem luzes e aberturas nos leitores.

Abril de 2017

(C) ETD-Educação Temática Digital Campinas, SP v.19 n.2 $\quad$ p. 305-306 abr./jun. 2017 